\title{
Upaya Peningkatan Prestasi Belajar Siswa pada Pembelajaran IPA tentang Benda dan Sifatnya melalui Penerapan Metode Eksperimen di Kelas III Sekolah Dasar
}

\section{Windiastuti}

SD Negeri Gununglarang 02

astutiwindi02@gmail.com

\section{Article History}

received $3 / 12 / 2020$

\begin{abstract}
This research generally aims to improve student learning achievement through the application of the Experimental Method in Mathematics Subjects Materials and Their Properties in class III SD Negeri Gununglarang 02 Academic year 2018/2019. In this study, it was carried out with two learning cycles and two meetings at each the cycle with research stages namely Planning, Implementation, Action and Reflection which focuses on increasing student achievement. The results of the research that has been carried out in the first cycle are as follows from 14 third grade students who experienced learning mastery only 8 students or 57\% the remaining 6 students or $42 \%$ had not experienced learning mastery while the average grade of the class was 70.3. cycle II with the following results students who experienced mastery learning had reached 12 students or $86 \%$ while the remaining 2 students or $14 \%$ did not experience mastery learning with an average value of 76.0. It can be concluded from the two cycles that have been implemented that The application of the Experimental Method in learning science material objects and their properties in class III SD Negeri Gununglarang 02 proved effective because it can improve student achievement.
\end{abstract}

Keywords: experimental method, learning achievement science

\begin{abstract}
Abstrak
Penelitian ini secara umum bertujuan untuk meningkatkan prestasi belajar siswa melalui Penerapan Metode Eksperimen pada Mata Pelajaran Matematika Materi Benda dan Sifatnya di kelas III SD Negeri Gununglarang 02 Tahun pelajaran 2018/2019.Pada penelitian kali ini dilaksanakan dengan dua siklus pembelajaran serta dua kali pertemuan pada setiap siklusnya dengan tahapan penelitian yaitu Perencanaan, Pelaksanaan, Tindakan serta Refleksi yang menitik beratkan pada peningkatan prestasi belajar siswa. Hasil penelitian yang telah dilaksanakan pada siklus I adalah sebagai berikut dari 14 siswa kelas III yang mengalamai ketuntasan belajar hanya 8 siswa atau $57 \%$ sisanya 6 siswa atau $42 \%$ belum mengalami ketuntasan belajar sedangkan nilai rata-rata kelasnya sebesar 70,3.Pembelajaran dilanjutkan pada siklus II dengan hasil sebagai berikut siswa yang mengalami ketuntasan belajar sudah mencapai 12 siswa atau $86 \%$ sedangkan sisanya 2 siswa atau $14 \%$ tidak mengalami ketuntasan belajar dengan nilai rata-rata sudah mencapai 76,0.Dapat disimpulkan dari dua siklus yang telah dilaksanakan bahwa Penerapan Metode Eksperimen pada pembelajaran IPA materi Benda dan Sifatnya di Kelas III SD Negeri Gununglarang 02 terbukti efektif karena dapat meningkatkan prestasi belajar siswa.
\end{abstract}

Kata kunci: metode eksperimen, prestasi belajar IPA

Social, Humanities, and Education Studies (SHEs): Conference Series https://jurnal.uns.ac.id/shes

p-ISSN 2620-9284

e-ISSN 2620-9292 


\section{PENDAHULUAN}

Dalam kegiatan belajar-mengajar, para guru pasti memiliki harapan-harapan tertentu terhadap siswanya. Setiap proses pembelajaran diharapkan mengalami belajar tuntas. Berdasarkan hal di atas, di kelas III SD Negeri Gununglarang 02 Kecamatan Salem Kabupaten Brebes, ternyata hasil ulangan untuk mata pelajaran IPA Kompetensi Dasar Membandingkan sifat-sifat benda berdasarkan wujudnya, nilai ratarata kelas masih rendah, dari 14 siswa yang tuntas belajar 70 ke atas hanya 3 siswa (21\%), sedangkan 11 siswa (79\%) mendapat nilai di bawah KKM yaitu 70 rata - rata nilai masih rendah yaitu 57,91 atau belum mengalami belajar tuntas. Menurut W.S Winkel (1996 : 53) Pengertian Prestasi adalah Bukti usaha yang dicapai pada suatu saat. Yaspir Ghandi Wirawan Dalam Wujono (1996 : 178) Prestasi belajar merupakan hasil yang dicapai oleh siswa dalam usaha belajarnya sebagai mana dicantumkan didalam nilai raportnya. melalui prestasi belajar seorang siswa dapat mengetahui kemajuan-kemajuan yang telah dicapai dalam prestasi belajar.

Dari segi istilah, IPA atau IImu Pengetahuan Alam berarti ilmu tentang pengetahuan alam. Pengetahuan Alam itu sendiri sudah jelas artinya adalah pengetahuan tentang alam semesta dengan segala isinya. Maslichah Asy'ari (2006: 7) menyebutkan bahwa IImu Pengetahuan Alam (IPA) berasal dari kata natural science. Natural artinya alamiah dan berhubungan dengan alam, sedangkan science artinya ilmu pengetahuan. IPA atau sains secara umum dapat dikatakan sebagai pengetahuan manusia tentang alam yang diperoleh dengan cara yang terkontrol.

Dari uraian latar belakang di atas, dapat dirumuskan masalah sebagai berikut Apakah penggunaan metode eksperimen/percobaan dengan menggunakan media pembelajaran berupa Balon,Gelas,air dan papan kayu pada mata pelajaran IPA dengan kompetensi dasar membandingkan sifat-sifat benda berdasarkan wujudnya, siswa Kelas III semester 1 SD Negeri Gununglarang 02 Kecamatan Salem Tahun Pelajaran 2019/2020 akan meningkat ?

Penelitian Tindakan Kelas secara umum bertujuan untuk menanggulangi masalah atau kesulitan dalam bidang pendidikan dan pengajaran agar hasilnya lebih baik, sehingga prestasi belajar siswa meningkat. Secara khusus laporan penelitian ini bertujuan:

1. Meningkatkan prestasi belajar mata pelajaran IPA siswa kelas III SD Negeri Gununglarang 02 Kecamatan Salem Kabupaten Brebes tahun pelajaran 2019/2020.

2. Memperoleh wawasan tentang pembelajaran yang efektif.

3. Mendeskripsikan penggunaan metode dan alat peraga dalam pembelajaran.

4. Menganalisis dampak kerja kelompok dalam pembelajaran terhadap hasil belajar siswa.

\section{METODE}

Penelitian ini merupakan Penelitian Tindakan Kelas (PTK) pada pembelajaran IPA dengan menggunakan Metode eksperimen.Subjek penelitian ini adalah siswa kelas III SD Negeri Gununglarang 02 Kecamatan Salem Kabupaten Brebes,semester I Tahun Pelajaran 2018/2019. Jumlah Siswa pada penelitian ini adalah 14 siswa dengan 2 siklus penelitian.

Jenis-Jenis Data yang di gunakan pada penelitian ini adalah:

1. Data Kualitatif

Data kualitatif adalah data yang berbentuk kata-kata, bukan dalam bentuk angka. Data kualitatif diperoleh melalui berbagai macam teknik pengumpulan data misalnya wawancara, analisis dokumen, diskusi terfokus, atau observasi yang telah dituangkan dalam catatan lapangan (transkrip). Bentuk lain data 
kualitatif adalah gambar yang diperoleh melalui pemotretan atau rekaman video.

2. Data Kuantitatif

Data kuantitatif adalah data yang berbentuk angka atau bilangan. Sesuai dengan bentuknya, data kuantitatif dapat diolah atau dianalisis menggunakan teknik perhitungan matematika atau statistika.

Pada setiap kegiatan penulis melakukan observasi dengan menggunakan instrument observasi untuk mengetahui aktivitas guru dan siswa. Dalam mengumpulkan data dan mendapatkan data, maka penulis menggunakan teknik-teknik sebagai berikut Teknik observasi yaitu melakukan pengamatan secara langsung ke objek penelitian siswa kelas III untuk mencatat aktivitas siswa dalam proses pembelajaran. Teknis Pengamatan yaitu Mengamati perilaku dan motifasi siswa dalam belajar IPA. Study Lapangan yaitu melakukan wawancara secara langsung kepada siswa mengenai PTK.Data yang terkumpul dianalisis secara kualitatif dan kuantitatif dengan persentase dan grafik. Jika data yang telah terkumpul lalu diklasifikasikan menjadi dua kelompok, yaitu data kualitatif dan kuantitatif.

\section{HASIL PENELITIAN DAN PEMBAHASAN}

Data yang diperoleh dalam perencanaan pelaksanaan perbaikan pembelajaran Penelitian Tindakan Kelas (PTK) ini berupa Rencana Perbaikan Pembelajaran (RPP) yang di dalamnya tercakup komponen skenario pembelajaran yang akan diimplementasikan dalam kegiatan belajar mengajar.

1) Siklus I dan II

a. Perencanaan

Pada tahap perencanaan penulis merencanakan pembelajaran pada siklus I,menyiapkan alat bantu pembelajaran yang sesuai dengan Materi Pelajaran Yaitu Benda dan Sifatnya yaitu dengan menggunakan Media Benda nyata seperti Botol,Balon,gelas dengan metode Eksperimen serta latihan instrument perlengkapan yang dibutuhkan antara lain Lembar Observasi,Lembar soal tes formatif dan lembar analisis penilaian,RPP,Diskusi dengan pihak yang membantu.Semua data sudah penulis persiapkan, dan dapat terlaksana dengan baik.

b. Pelaksanaan

Pelaksanaan perbaikan pada siklus I dilaksanakan 2 kali pertemuan,Prosedur pelaksanaan dilaksanakan sesuai rencana pelajaran pada umumnya.

Data yang berupa nilai dari hasil tes formatif yang telah dilaksanakan baik Study Awal, siklus I, maupun siklus II dimasukan ke dalam table nilai. Setiap siklus nilainya dipisahkan untuk memudahkan dalam membandingkan perolehan nilai dari setiap siklus, sehingga tahu tahap perkembangan kemampuan siswa tahap demi tahap , seperti di bawah ini :

Tabel 1. Tingkat Ketuntasan Belajar

\begin{tabular}{|c|c|c|c|c|c|}
\hline \multirow{2}{*}{ No } & \multirow{2}{*}{ Uraian } & \multicolumn{2}{|c|}{ Siswa Tuntas } & \multicolumn{2}{|c|}{ Siswa Tidak Tuntas } \\
\hline & & $\mathbf{F}$ & $\%$ & $\mathbf{F}$ & $\%$ \\
\hline 1 & Studi Awal & 3 & $21 \%$ & 11 & $79 \%$ \\
\hline 2 & Siklus I & 8 & $57 \%$ & 6 & $42 \%$ \\
\hline 3 & Siklus II & 12 & $86 \%$ & 2 & $14 \%$ \\
\hline
\end{tabular}




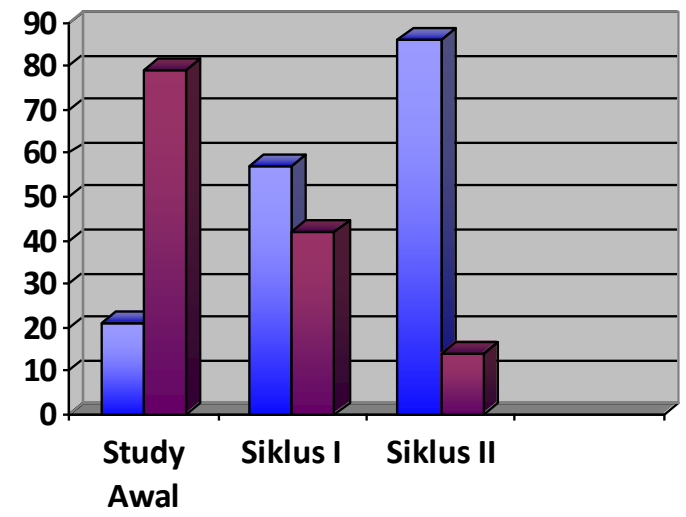

$\square$ Tuntas \%

Tidak Tuntas \%

Gambar 1 Diagram Ketuntasan Belajar Study Awal,Siklus I dan Siklus II

Tabel 2. Tabel aktifitas siswa dalam pembelajran

\begin{tabular}{cccccc}
\hline \multirow{2}{*}{ NO } & \multirow{2}{*}{ Uraian } & \multicolumn{2}{c}{ Aktif } & \multicolumn{2}{c}{ Tidak Aktif } \\
\cline { 3 - 6 } 1 & Studi Awal & 3 & $21 \%$ & 11 & $79 \%$ \\
\hline 2 & Siklus I & 8 & $57 \%$ & 6 & $42 \%$ \\
\hline 3 & Siklus II & 12 & $86 \%$ & 2 & $14 \%$ \\
\hline
\end{tabular}

Dari tabel diatas dapat dijelaskan bahwa Pada study awal persentase keaktifan siswa baru mencapai 21\% Siklus I 54\% dan Siklus II 86\% dengan demikian persentase keaktifan siswa selalu meningkat tiap siklusnya.
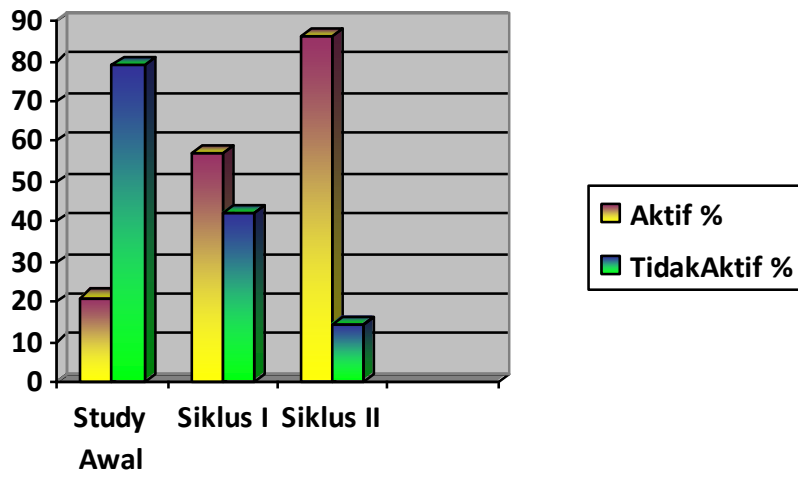

\section{Gambar 2. Diagram Aktifitas Siswa Study Awal,Siklus I dan Siklus II}

Dari hasil pengamatan diketahui bahwa kekurangan yang ada pada Pembelajaran Study Awal, siklus I sudah diperbaiki dalam pelaksanaan siklus II. Nilai siswa sudah mencapai target ketuntasan, juga prestasi belajarpun meningkat. Guru juga sudah mengoptimalkan penggunaan media dan Metode pembelajaran. Adapun 
hasil dari Pembelajaran dan aktifitas siswa Study Awal Siswa Tuntas 3 (21\%) belum tuntas $11(79 \%)$ nilai rata rata kelas sebesar 57,9 dengan tingkat aktifitas siswa sebesar $21 \%$, selanjutnya Siklus I Siswa tuntas $8(57 \%)$ belum tuntas $6(42 \%)$ sedangkan rata-rata kelas sebesar 70,3 dan aktifitas siswa sebesar $57 \%$ dan Siklus II Siswa tuntas $12(86 \%)$ belum tuntas $2(14 \%)$ nilai rata-rata kelas sebesar 76,0 dan aktifitas siswa sudah mencapai $86 \%$.

Dengan demikian penulis yakin bahwa Penerapan Media Benda Nyata dan Metode Eksperimen dapat meningkatkan aktifitas dan Prestasi Belajar Siswa pada Pembelejaran IPA di Kelas III SD N Gununglarang 02 Semester 1 tahun Pelajaran 2018/2019.

Penulis memilih Media Pembelajaran atau alat peraga sebagai alat dalam mengatasi kesulitan belajar anak, karena pertama dengan media ini ternyata dapat meningkatkan perhatian, pemahaman, dan motivasi siswa dalam kegiatan pembelajaran.

\section{SIMPULAN}

Hasil dari melaksanakan proses perbaikan pembelajaran mata pelajaran IImu Pengetahuan Alam/Sains kompetensi dasar Membandingkan Sifat-Sifat benda berdasarkan Wujudnya dengan penerapan metode eksperimen/percobaan dengan pendekatan media benda nyata berupa (Balon, Gelas, Air), di kelas III semester 1 SD Negeri Gununglarang 02 Kecamatan Salem Kabupaten Brebes dengan hasil yang memuaskan. Hal ini dapat penulis simpulkan bahwa :

1. Penerapan metode eksperimen/percobaan sangat sesuai untuk menyampaikan materi pelajaran Membandingkan Sifat-sifat benda berdasarkan wujudnya pada mata pelajaran IPA di kelas III semester I.

2. Penggunaan media pembelajaran berupa benda nyata (Balon,Air,Gelas) kompetensi dasar Membandingkan Sifat-sifat benda berdasarkan wujudnya di kelas III semester 1, dapat meningkatkan pemahaman, partisipasi dan motivasi siswa.

3. Dengan memberikan kesempatan pada siswa untuk melakukan percobaan,dan mengerjakan LKS siswa memahami secara langsung konsep yang disampaikan guru.

Saran dan tindak lanjut yang dapat dilakukan yaitu (1) Mempersiapkan rencara pembelajaran yang baik, sebab dengan perencanaan yang baik tentu hasilnya pun akan baik pula; (2) Mempersiapkan media dan Metode pembelajaran yang sesuai dengan materi yang akan disampaikan, sebab dapat meningkatkan perhatian, pemahaman, serta motivasi anak terhadap pelajaran; (3) Menguasai materi pelajaran, sebab dengan penguasaan materi yang baik setidaknya siswa akan segan pada kita; (4) Guru dalam mengajar selalu menggunakan rencana pembelajaran; (5) Membimbing siswa yang tidak tuntas; (6) Siswa yang daya serap rendah dan selalu mendapat nilai terendah di kelasnya di anjurkan untuk mengikuti kegiatan belajar di luar sekolah seperti LES atau sejenisnya

\section{DAFTAR PUSTAKA}

Hadiat, dkk (2004). Ilmu Pengetahuan Alam untuk Sekolah Dasar Kelas 3. Jakarta : Balai Pustaka.

Haryanto (2004), Ilmu Pengetahuan Alam (Sains) untuk Sekolah Dasar Kelas 3. Jakarta : Erlangga.

Arikunto, Suharsimi. 2010. "Prosedur Penelitian Suatu Pendekatan Praktik". Jakarta: Rineka Cipta.

Haryanto Nar, H.M. Akib Hamid. (2003). Statistika Dasar. Jakarta : Universitas Terbuka. 
Herry Hernawan Asep, dkk. (2006), Pengembangan Kurikulum dan Pembelajaran. Jakarta : Universitas Terbuka.

Suparno, Yunus Muhammad. (2003). Ketrampilan Dasar Menulis. Jakarta : Universitas Terbuka.

Darmawan Deni. 2013. “Metode Penelitian Kuantitatif'. Bandung: PT Remaja Rosdakarya.

Hendri adi. 2010. "Guru Berkualitas: Profesional dan Cerdas Emosi". Jurnal saung guru, 1(2): 3.

Suroso Ario. (2004). Komputer Dan Media Pembelajaran. Jakarta, : Universitas Terbuka.

Wardani I.G.A.K, dkk. (2003). Penelitian Tindakan Kelas. Jakarta : Universitas Terbuka.

Wijaya Cece, dkk . (1988). Upaya Pembahasan dalam Pendidikan dan Pembelajaran. Bandung : Remaja Karya.

Zaenul Asmawi dan Mulyana Agus. (2005). Tes dan Asesmen di SD. Jakarta : Universitas Terbuka.

Kosasih. (2014). Strategi Belajar dan Pembelajaran Implementasi Kurikulum 2013. Bandung: Penerbit Yrama Widya.

Samatowa, Usman. (2011). Pembelajaran IPA di Sekolah Dasar. Jakarta: PT Indeks.

Sugiyono. (2006). Metode penelitian Kuantitatif, Kualitatif dan R\&D. Bandung: Alfabeta CV. 